Portland State University

PDXScholar

$5-19-1978$

\title{
An Analysis of the Relationship Between Personality Characteristics of Social Work Students and Choice of Social Work Practice Area
}

Linda A. Yegge

Portland State University

Francie E. Buktenica

Portland State University

Follow this and additional works at: https://pdxscholar.library.pdx.edu/open_access_etds

Part of the Personality and Social Contexts Commons, and the Social Work Commons Let us know how access to this document benefits you.

\section{Recommended Citation}

Yegge, Linda A. and Buktenica, Francie E., "An Analysis of the Relationship Between Personality Characteristics of Social Work Students and Choice of Social Work Practice Area" (1978). Dissertations and Theses. Paper 2841.

https://doi.org/10.15760/etd.2835

This Thesis is brought to you for free and open access. It has been accepted for inclusion in Dissertations and Theses by an authorized administrator of PDXScholar. Please contact us if we can make this document more accessible: pdxscholar@pdx.edu. 
An Analysis of The Relationship

Between Personality Characteristics of Social Work Students and Choice of

Social Work Practice Area

by

Linda A. Yegge and Francie E. Buktenica

Submitted in partial. fulfillment

of the requirements for the degree of

Masters of Social Work

Portland State University

1978 
TO THE OFFICE OF GRADUATE STUDIES AND RESEARCH:

The members of the Committee approve the practicum of

Francie E. Buktenica and Linda A. Yegge, presented May 19, 1978,

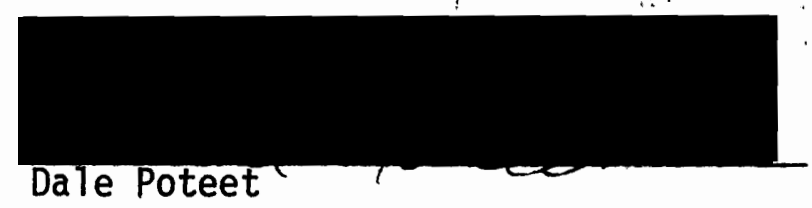

Nancy Korgloff 


\section{ACKNOWLEDGEMENTS}

Love and thanks to our families for patience and support,

F. Robert Stuckey, Ph.D., for his assistance with typology research, Dale Poteet, M.S.W., for his encouragement and advice and Nancy Koroloff, M.S.W., for comments and assistance with research statistics.

$$
\text { F. B. and L. Y. }
$$




\section{ABSTRACT}

Due to curiosity about the "individual" vs. "social" intervention argument in the profession of social work, the authors of this study attempted to answer the question, "Do personality characteristics of Social Work Graduate Students influence their choice of social work practice?" Our hypothes is was that Introverts would be more inclined to focus on the individual in social work practice as opposed to Extraverts who would see societal change as a more pressing practice issue. Although our study identified no correlation between Introversion and Extraversion and social work practice orientation, there were some suggestions for further study. There appeared to be some indication that Intuition and Feeling might be more important variables. The idea was also raised that the conflict among social workers might be more a result of the nature of their personality type than a real dichotomy in the field. 
TABLE OF CONTENTS

PAGE

ACKNOWLEDGEMENTS . . . . . . . . . . . . . . i i

ABSTRACT .......................... iv

LIST OF TABLES ............................ vi

CHAPTER

I INTRODUCTION ........................... 1

II DESCRIPTION OF THE PROBLEM .......... 2

Focus ............... 2

Purpose .............. 3

III REVIEW OF THE LITERATURE ........... 6

The Social Work Cause-Function Dilemma . . 6

Jungian Personality Typology ....... 10

IV METHODS AND TECHNIQUES ........... 13

Hypothesis ............ 13

Test Group ........... . . 13

Instruments ........... . 13

Myers-Briggs Type Indicator

Description ........ 13

Reliability and Validity Studies . 22

Baker-Schulberg Community Mental

Health Inventory

Description ... . . . . 24

Reliability and Validity Studies . 25

Additional Studies ...... 30 
V PROCEDURE................. 33

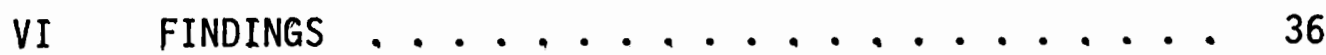

Summary ... . . . . . . . . 43

VII DISCUSSION ................ 45

VIII RECOMMENDATIONS .............. 47

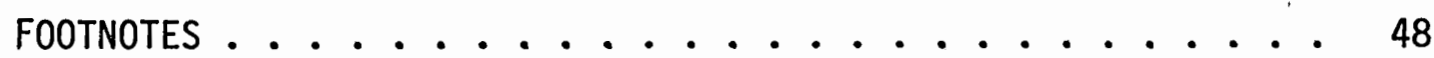

BIBLIOGRAPHY . . . . . . . . . . . . . 53

APPENDIX

NUMBER 1 DEMOGRAPHIC SHEET . . . . . . . 59

NUMBER 2 FIELD PREFERENCE QUESTIONNAIRE ...... 60

NUMBER 3 FEBRUARY 1,1978 LETTER . . . . . . 62

NUMBER 4 FEBRUARY 20, 1978 LETTER . . . . . . 63

NUMBER 5 MARCH 27, 1978 LETTER ......... 64

NUMBER 6 COVER LETTER FOR FIELD PREFERENCE

QUESTIONNAIRE ......... 65 


\section{LIST OF TABLES}

TABLE

PAGE

I Combinations of Perception and Judgement

Compared .................. 19

II Basic CMHI Scale Data for Criterion Groups . . . . . 27

III CMHI Scale Data for Professional Groups . . . . . . 31

IV Age as Compared to CMHI Scores ........... 37

V Sex as Compared to CMHI Scores ........... 37

VI Comparison of the Range of CMHI to

Work Preference ........... . . 39

VII Comparison of MBTI Types and CMHI Mean Scores . . . . 42 


\section{CHAPTER I}

\section{INTRODUCTION}

The specific question raised by this investigation will be: Is there an identifiable personality difference between social work students who see the individual as the focus for social work intervention, as opposed to those who see society as the central issue?

The format of this research will be organized by initially presenting the rationale for the study in Chapter II, including a statement of purpose. Chapter III reviews the "individual" vs. "society" issue recorded in the social work literature. The balance of the literature presented describes personality type theory from a Jungian framework. Chapter IV presents the tools chosen to measure and describe the social work practice preferences and personality type of the second year social work graduate students studied. Procedure for collecting data is outlined in Chapter V. Chapter VI contains a description and summary of the findings of this research. A discussion of the implications of the study is offered in Chapter VII, with final recommendations for further research presented in Chapter VIII. 


\section{CHAPTER II \\ DESCRIPTION OF THE PROBLEM}

\section{Focus}

Interest in the issue identified by the present investigation was generated in the authors by their experience of social work education at Portland State University. By the second quarter of first year graduate training, the authors, numbered among 86 masters leve] students, were embroiled in a controversy concerning the philosophy and practice of the social work profession. The issue behind the conflict, arising both in and out of the classroom, seemed to center on whether the social work profession ought to focus its efforts on the individual or on society. Should social workers aid the individual in strengthening his coping mechanisms and help him learn to effectively deal with his often stressful environment, or should social workers attempt to improve the individual's environment through societal changes, thereby reducing the stress on the individual?

This conflict was and still is not easily resolved by these social work students nor did it seem to be easily resolved for the profession as a whole. Social work identified such a clinical vs. social orientation conflict in its literature and this professional conflict appeared to be clearly operating in the educational atmosphere of the Portland State University School of Social Work. It became a continual 
focus of discussion in classes, and some instructors, though swearing a lack of bias, appeared to have decided and firm opinions on the matter. For many, students and instructors alike, there appeared to be no common ground. Heated discussions often dissolved into emotional, value laden shouting matches. The authors, finding themselves taking one stance or another, began to take a curious look at what, if anything, lay behind the either/or approach to social work practice. In considering the issue, the authors, out of their own interest in personality theory, began to wonder if an individual's philosophy of social work practice might be related to some aspect of his or her personality and, thus, his or her perception of life.

\section{Purpose}

As mentioned earlier, further investigation of this question leads to an extensive history of just such a controversy within the field of social work as a whole. It was decided that if one could explain why such a conflict thrived on a college campus where social work is taught, then the conclusions might have some bearing on the professional conflict in the field in general. If, in fact, it could be determined that personality might have an influence upon the emhasis an individual places on social work practice, then there might be a means of understanding the conflict for those involved.

To emphasize the importance of understanding in situations of conflict, it might be important to look for a moment at marital confijct as an example where a similar process might also evolve. Often 
marriage partners, coming together out of love and respect for one another, share similar interests, beliefs, or goals. After some initial time has passed in the relationship, the couple may become more aware of their true differences. These differences, many times, balance the couple in terms of their overall skills. Each partner compensates for what the other lacks. The couple has more of a sense of "wholeness". Yet the same diversities may also cause conflicts. For example, a man who likes to go on a trip on the spur of the moment is greatly frustrated by a wife who wants to sit and plan the trip in detail before leaving the house.

Such analysts as Margit Van Leight Frank ${ }^{1}$ suggest that couples will survive these disagreements only if they come to an understanding that each partner perceives the world from a different framework. Dr. Frank states, "In the realm of marriage, the recognition of the different psychological types has a most dramatic effect in bringing about better understanding and adjustment to conflicting views, and the cessation of the violation of the other person's standpoint."2

The purpose of this study is to identify if the specific personality characteristics of introversion and extraversion in social work graduate students influence their choice of emphasis in social work practice. In other words, do introverts tend to focus on the individual in practice and do extraverts emphasize societal interventions? If specific personality characteristics are identified, then it might make it possible to foster some understanding by the profession of its conflicts. In this way, social work, like marriage might survive its 
internal conflicts by understanding, accepting, and making positive use of the varieties and diversities of its parts. To restate Dr. Frank in the present context, social workers with divergent viewpoints might not fall into the destructive pattern of "violating the other person's standpoint."3 


\section{REVIEW OF THE LITERATURE}

In order to provde a sufficient theoretical background to answer the question raised by this investigation, it is necessary to review the literature with two major areas of emphasis. First, we will examine the history of the "individual" vs. "society" issue as it has evolved over the years in the profession of social work. Secondly, the Jungian theory of Personality Typology is described in order to define the personality characteristics of introversion and extraversion.

\section{The Social Work Cause-Function Dilemma}

The basic conflict of where the social worker should focus his or her energy, is not merely an idle intellectual exercise tossed about by graduate students in the process of stretching their minds. The field of social work has, since its beginnings, been caught up in this controversy. Is it man against himself in intrapsychic terms, or man against malevolent forces? The tendency is to dichotomize social reconstruction and individual treatment as an either/or proposition, disregarding the wide range of needs and appropriate responses. History has shown that the pendulum swings from one emphasis to another.

The profession of social work began with the belief that man 
should be viewed and helped with regard to his social situation. Mary Richmond, the mother founder of social casework, in 1922 declared:

The whole of social work is greater than any of its parts. All parts serve personality . . . Casework serves it by effecting better adjustments between individuals and their social environment . . Social reform serves it by effecting mass betterment through propaganda and social legislation. 4

In this statement, Mary Richmond was making the first comment upon the synchronization of social work efforts that touch both the individual as well as society. As a result, during the Progressive Era of our nation, social work was characterized by a close association between individualized help and social reform. According to Clarke Chambers in his book Seedtime of Reform, "the alliance of social reformer and social servant in this period was an intimate one, cemented by common cause and long friendship." 5

In the 1920's, the work of Freud opened new vistas in understanding and dealing with the problems of maladjustment. Freudian psychiatry had its impact. Roy Lubove explains the tenor of belief at this time:

If reality was rooted not in the objective environment but in the individual's emotional and intellectual perception of the environment . . . then caseworkers wrestled with superficialities if they concentrated upon external manipulation instead of the clients' psychic life. 6

This change in emphasis "from environment to the meaning of experience within the psyche",7 broadened the knowledge base of the profession's efforts directed toward the individual, but simultaneously led to a rift in the friendship of social workers.

Countering this emphasis on the individual were social workers 
concerned with the economic and environmental issues brought to bear by the depression of the late 1920's. Problems of hunger, housing, and unemployment caused a shift in focus for social work intervention back to the environment. 8

By this time, a pattern of pendulum-like movement in social work focus had begun to emerge and in 1929, Porter Lee made an effort to tackle the more negative extreme divisions within the social work profession. He first gave the issue its name, "Cause-Function." 9 He defined "cause" as a "movement directed toward the elimination of an entrenched evil."10 He saw "function" as the making permanent in direct service the results of this movement. He stated:

The appeal of cause is to the sympathy of men, their sense of justice, their humanitarian instincts . . . The appeal of function depends more on reaching the intelligence of men and their sense of social obligation. 11

Porter Lee advocated the need for both cause and function to work together in harmony. He said, "Civilization is dead unless it retains the capacity to develop new ideas as well as ensure permanency and efficiency of those which it has given corporate life." 12 Porter Lee's attempts to reconcile the practice conflict focused on the individual or society appeared to fall on deaf ears. By the 1930's and 40 's another shift back to individual intervention appeared to gain popularity with social work practitioners. Roy Lubove, 13 Ernest Hollis and Alice L. Taylor 14 among others reported concern over this growing trend. Circumstances in field practice were so unbalanced surrounding this issue that it prompted Helen Perlman in 1952 to ask that the profession "put the social back in social casework." 75 
Charlotte Towle called for a renaissance of the unity of cause and function in the profession. She felt that social work must make the effort to unify the two, finding cause in the promotion of the welfare of the individual in society and function in the implementation of the cause. 16 By the 1960's it appeared that such divisions of purpose had led to the failure of the profession to take the lead in solving the current issues of poverty, civil rights, and mental heal th. 17

A solution proposed at that time by Eveline Burns was to divide the profession into two distinct schools, licensing practitioners who deal in clinical therapy and separating them from community organizers and planners. 18 William Schwartz reacted to such a solution by stating:

A half licensed profession would indeed be a living symbol of the schizophrenia induced by the failure to understand the connections between private troubles and public issues. 19

As recently as 1965, Alfred Kahn, addressing the NASW Tenth Anniversary Symposium stated the issue in the familiar either/or terms by asking whether social work would make its best efforts in the realm of the "clinical-therapeutic-rehabilitative core" or change itself to "a primary discipline of a social planning state."20 Obviously, the problem appears to remain an important one, currently disputed from one side to another.

Remembering back, though, to 1929, one can see that Porter Lee indicated what may have been the source of the problem all along. 
He stated:

Few individuals seem to have combined within themselves the qualities of the dynamic leader of the cause and the efficient executive in charge of the function. The two do not often appear at their best within one temperament. 21

The authors tended to feel that this might be an answer to the dilemma. Maybe temperament or more aptly personality, might be the key to the intense differences of opinion about what social workers ought to be doing.

\section{Jungian Personality Typology}

In 1921, a Swiss Psychoanalyst, Carl G. Jung wrote a volume entitled, Psychological Types. In this work, Jung describes the various attitudes the conscious mind might take toward the world. Jung termed the two basic attitude types as introversion and extraversion. 22 This theory explains that the extravert's energy flows outward to the object. Objective facts or external happenings are the most important factors of life for him. People, things, and events are endlessly interesting to him and he adapts himself easily and well to his environment. His mind is stimulated by the object. He reacts to it on a specific basis and does not tend to either generalize or introspect from it. He talks fluently, makes friends easily and is, in general, a usefur and appreciated member of society.

The energy of the introvert is directed predominantly inward. For the introvert, the significance of the object lies not in itself but in how it relates to his own psychology. It is not the situation objectively considered, but the situation as he reacts to it subjec- 
tively that is the dominating factor. The introvert prefers his own inner life where he is quite at ease. He can endure solitude and must have a considerable amount of it for his mental health. The introvert cultivates friends but tends to limit them in number. It might also be said that the introvert forms vertical (depth) relationships as opposed to the horizontal (breadth) relationships of the extravert. Extraverts are involved with the outer world of people and things, while introverts are more involved with the inner world of concepts and ideas.

In the literature a few studies attempt to substantiate Jung's typological theory with regard to introversion and extraversion. In line with the Jungian notion that extraverts have a greater action orientation than introverts, Tranel $(1962)^{23}$ and Ross $i$ and Solomon $(1965)^{24}$ found that extraverts and introverts reacted significantly different to sensory deprivation. Both studies found that extraverts tended to modify the external environment of the experimental settings in order to alleviate discomfort.

The extravert's tendency to be more involved with the external world was supported by a 1971 investigation by Veach and Toukey. 25 They found that extraverts were more accurate perceivers of time than introverts. Mann (1956) 26 also reported a significantly different response to environment between Introversion and Extratension scores on the Rorschach.

Shapiro and Alexander $(1968)^{27}$ found that, presented with a subject seeking a solution to his difficulties, introverts tend to see 
the subject as more self-reliant and more active in his reactions. He can handle his situation alone. Extraverts described the subject as less assertive and more passive. Responsibility to alleviate the subject's difficulty is seen as coming from the help of others. In an experiment, Shapiro and Alexander also discovered that under conditions of anxiety and stress, introverts chose to be alone, while extraverts sought affiliation with others. 
CHAPTER IV

METHODS AND TECHNIQUES

Hypothes is

There will be no correlation between introverted personality type as measured by the MBTI and low scores on the Baker-Schulberg CMHI (Community Mental Health Inventory).

There will be no correlation between extraverted personality type as measured by MBTI and high scores on the Baker-Schuiberg CMHI.

\section{Test Group}

The subjects in this study are the 68 second year Social Work Graduate Students enrolled in classes during the Winter and Spring Terms of 1978 at Portland State University.

\section{Instruments}

\section{Myers-Briggs Type Indicator (MBTI)}

1. Description

The MBTI is a self-administered, "forced" choice paper and pencil test containing 166 items. The test was designed by Katherine Briggs and Isabel Myers to implement in a practical manner, Jung's theory of personality type. It ascertains each individual's 
preferences, one for each of the four (4) following indices:

E I Extraversion or Introversion

$N \quad S$ Intuition or Sensation

$T \quad F \quad$ Thinking or Feeling

$J \quad P \quad$ Judging and Perceiving

The EI index, discussed earlier, is designed to identify an individual's orientation toward life. The extravert is oriented to the outer world and environment, focusing his perception and judgment upon people and things. The introvert is oriented to the inner world of the individual and focuses his perception and judgement upon concepts and ideas.

The SN index identifies the individual's preferences between two modes of perception. "Perception" is defined by the MBTI Manual as "a process of becoming aware--of things or people or occurrences or ideas."28 The term "sensation" refers to sense-perception, that is, through the five senses. The sensation type perceives through his senses. Outer and inner spontaneously sensed convictions constitute reality for him. He perceives these realities as they exist now, in the present.

The intuitive's psychological function transmits perceptions via the unconscious. Intuition is an immediate awareness of the whole configuration without a real comprehension of the details of the contents. It concerns itself with inner and outer phenomenon. The focus is on possibilities.

The sensation type is interested in things as they are now, the 
intuitive sees things in potential as they might be. The solid inner and outer facts preferred by the sensation type tend to be uninteresting to the intuitive, and the possibilities which are so full of life for the intuitive have little meaning for the sensation type.

The TF index reflects the person's preference between two opposite ways of judging, that is "the process of coming to conclusions about what has been perceived."29 Jung considered the thinking type as one whose every important action proceeds from intellectually considered motives. A thinking type discriminates impersonally between true and false. He meets a situation with logical thought, shaping his actions by conclusions. Thinking takes into account all the known content. It cannot be isolated in the form of a mood. It classifies and names things.

Feeling imparts to the content a definite value in the sense of acceptance or rejection, valued or not valued. The feeling function is personal; it represents the individual's acceptance or rejection of something based on his own values more than its intrinsic worth. The feeling function is chiefly concerned with values and morality. The last index, JP, is designed to reflect whether the individual relies predominately on the judging process ( $T$ or $F$ ) or on a perceptive process ( $S$ or $N$ ), indicating that one process is dominant and the other is the auxiliary process. Both processes must be used throughout an individual's lifetime but both cannot be used at the same time. In a discussion of the JP preference, Isabel Myers states: 
Almost all people enjoy one attitude more than the other, find it more comfortable, feel more at home in it, and spend much of their lives in it as is possible. There is a fundamental difference between the two attitudes. In the judging attitude, in order to come to a conclusion, perception must be shut off for the time being. The evidence is all in. Anything more is incompetent, irrelevant, and immateriai. One now arrives at a verdict and gets things settled. Conversely, in the perceptive attitude one shuts off judgement for the time being. The evidence is not all in . . . New developments will occur. It is much too soon to do anything irrevocable.. Both attitudes have their merits. Either can make a satisfying way of life, if one is able to switch over temporarily to the opposite attitude when he really needs it. 30

Scoring of the MBTI is performed by hand with separate sets of keys for each of the eight (8) types. It identifies with a higher score, the four (4) major preferences, one for each of the four (4) indices: EI, NS, TF, and JP. Also, on the TF index, item weights are different for males and females, and separate keys must be used for each sex.

The MBTI has been used primarily in psychoanalysis to help enable an individual to understand his own personal field of choices. Results have also been used in vocational counseling, college preparatory counseling, marriage counseling and employment settings (for maximum potential use of the individual's skills). 31

Combinations of Perceptive Types ( $S$ or $N$ ) and Judging Types ( $T$ or F) have been compared to describe their attributes and abilities in terms of employment settings. Table $\mathrm{I}^{32}$ describes this comparison as delineated in the MBTI Manual and also lists classifications as identified by four different studies: Thurstone (1931), Gundlach and Gerum (1931), Spranger (1928), and Murray (1938). 
Also supporting such descriptions is a report by Harold W. Grant (1965) who studied the behaviors of MBTI Types. ${ }^{33}$ An 85 item questionnaire was administered to 1,413 freshmen students at Auburn University. The MBTI was also administered to all subjects. Questionnaire responses were grouped by particular type separating those responses specifically differentiating one type from another. Results were compiled in a summary for each type. These descriptions were significantly similar to those presented in the manual.

The MBTI has also been studied in comparison with other tests. Scores have been compared to the Gray-Wheelwright Psychological Type Questionnaire, an independently constructed test designed to identify $E, I, N, S, T$ and $F$ types. Harold Grant was also responsible for this 1965 study, ${ }^{34}$ which found that (lacking the JP scores) both the MBTI and Gray-Wheelwright reflect the reality of opposites as defined by Jung among the indices tested.

Other correlations have been computed with the Strong Vocational Interest Blank (SVIB), the AVL Study of Values, the Edwards Personal Preference Schedule (EPPS), the Personality Research Inventory, with Faculty Ratings, with Turnover in Utility Jobs, and with Ratings of Creativity. Relationship of types has also been studied with regard to aptitude (IQ). 35

A number of studies have been independently launched to investigate various aspects of the MBTI and its relationship to Jung's Theory of Typology. David O. Hill, in a Doctoral Thesis $(1970)^{36}$ 
studied the Extraversion-Introversion index. Richard V. Peavy (1963), ${ }^{37}$ at the University of Oregon concentrated on the IntuitiveSensation opposites as defined by Jung and measured by the MBTI. Goldschmid ${ }^{38}$ (1967) and Stroops (1971) (19) $^{39}$ studied different college majors to identify the vocational interests and personality types of these students. Goldschmid was able to correlate sensation and thinking to humanities. For males, in particular, he was able to find a correlation of extraversion with science majors and intuition and perception with humanities majors. Stroops, on the other hand, studied women teacher education majors in the areas of 1) Health and Physical Education and 2) Home Economics. In the first discipline, she found predominately ESFP types, whereas the second group was primarily made up of ESTP types.

In a 1967 Doctoral Thesis presented at the University of Illinois, Thomas McNamara ${ }^{40}$ studied counselor trainees in the areas of philosophical orientation (e.g. realist and existential) and counseling performance ratings. He found that NF types as tested by the MBTI generally received higher rankings on the performance criteria dimensions. He stated, "NF types are concerned with philosophical assumptions of counseling and feel a need for philosophical adequacy of some kind in their work as counselors. "4T

Jerry Lee Terri11 (1969) 42 studied 58 counselors and 20 principals from 20 secondary schools in the Denver suburban area and found that "administrators appear to differ from counselors in their preference for thinking rather than feeling approaches to judgement 
and in preference for judging processes rather than perceptive processes."43 Both administrators and counselors were noted for their preferences for intuition and extraversion as opposed to sensation and introversion.

Table I

COMBINATIONS OF PERCEPTION AND JUDGMENT, COMPARED

\begin{tabular}{|c|c|c|c|c|}
\hline $\begin{array}{l}\text { People who } \\
\text { prefer }\end{array}$ & $\begin{array}{l}\text { SENSING } \\
+ \text { THINKING }\end{array}$ & $\begin{array}{l}\text { SENSING } \\
+ \text { FEELING }\end{array}$ & $\begin{array}{l}\text { INTUITION } \\
+ \text { FEELING }\end{array}$ & $\begin{array}{l}\text { INTUITION } \\
+ \text { THINKING }\end{array}$ \\
\hline $\begin{array}{l}\text { focus their } \\
\text { attention on }\end{array}$ & Facts & Facts & Possibilities & Possibilities \\
\hline $\begin{array}{l}\text { and handle } \\
\text { these with }\end{array}$ & $\begin{array}{l}\text { Impersonal } \\
\text { analys is }\end{array}$ & $\begin{array}{l}\text { Personal } \\
\text { warmth }\end{array}$ & $\begin{array}{l}\text { Personal } \\
\text { warmth }\end{array}$ & $\begin{array}{l}\text { Impersonal } \\
\text { analysis }\end{array}$ \\
\hline $\begin{array}{l}\text { Thus they } \\
\text { tend to be }\end{array}$ & $\begin{array}{l}\text { Practical and } \\
\text { matter-of-fact }\end{array}$ & $\begin{array}{l}\text { Sociable and } \\
\text { friendly }\end{array}$ & $\begin{array}{l}\text { Enthusiastic } \\
\& \text { insightful }\end{array}$ & $\begin{array}{l}\text { Intellectually } \\
\text { ingenious }\end{array}$ \\
\hline $\begin{array}{l}\text { and find scope } \\
\text { for their } \\
\text { abilities in }\end{array}$ & $\begin{array}{l}\text { Production } \\
\text { Construction } \\
\text { Accounting } \\
\text { Business } \\
\text { Economics } \\
\text { Law } \\
\text { Surgery } \\
\text { Etc. }\end{array}$ & $\begin{array}{l}\text { Sales } \\
\text { Service } \\
\text { Customer } \\
\quad \text { relations } \\
\text { Welfare work } \\
\text { Nursing } \\
\text { Gen. practice } \\
\text { Etc. }\end{array}$ & $\begin{array}{l}\text { Research } \\
\text { Teaching } \\
\text { Preaching } \\
\text { Counselling } \\
\text { Writing } \\
\text { Psychology } \\
\text { Psychiatry } \\
\text { Etc. }\end{array}$ & $\begin{array}{l}\text { Research } \\
\text { Science } \\
\text { Invention } \\
\text { Securities } \\
\text { analysis } \\
\text { Management } \\
\text { Cardiology } \\
\text { Etc. }\end{array}$ \\
\hline
\end{tabular}

Recognized by

Thurstone as

interested in Business

People

Language

Science

Gundlach and

$\begin{array}{llll}\text { Gerum as } & \text { Technical } & \text { Social } & \text { Creative } \\ \text { Spranger as } & \text { Economic } & \text { Social } & \text { Religious } \\ \text { Murray as } & \begin{array}{l}\text { Practical, } \\ \text { skeptical, } \\ \text { down-to-earth }\end{array} & \begin{array}{l}\text { Imaginative, } \\ \text { subjective, } \\ \text { human }\end{array}\end{array}$

Intellectual

Theoretical 
One of the most striking investigations was completed by Michae1 T. Yura (1971). ${ }^{44}$ He focused his efforts on a sample of 111 graduate students in the guidance department at Ohio State University. In his study of personality traits and vocational interests, he found a predominance of $E F$ and IF types.

Rae Carlson and Nissim Levy have done two studies, one involving social-personal orientations, and the other focusing on preferences of types for social action. In their 1968 study, ${ }^{45}$ Carlson and Levy looked at the individual's self-concept by comparing the responses of subjects to the Carlson Check List and the MBTI. The Social Personal Orientation is the tendency of an individual to "define one's self-concept either in terms of social relationships or in terms independent of social relationships." 46 Results indicated that socially orientated persons would more likely utilize the more "'emotional', object-oriented functions of sensing and feeling" and personally oriented individuals would prefer "more 'rational' inneroriented functions of thinking and intuition." 47 Although the issue of extraversion-introversion is not addressed specifically in this study, the reference to socially oriented persons as being objectoriented and personally oriented individuals as inner-oriented, appears to point to this possible definition as well as a support to the investigation of this present study.

The 1973 Carlson-Levy investigation attempts to substantiate the use of the MBTI in studying person-situation interactions in terms of "an individual's basic stance toward the environment and his 
'natural' modes of perceiving and judging experience." 48 In this report, Carlson \& Levy focus on the four following studies:

1. Type Difference in Memory Task Performance (Short Term Memory)

2. Type Difference in Memory Task Performance (Re-test)

3. Type Differences in Social Perception (Interpreting Facial Expressions of Emotion)

4. Personality Type and Volunteering for Social Service (Halfway House Volunteers for Adolescents)

In each of the studies, a type was projected for the task or practice area. The fourth study projected that the social service volunteers would be predominately extraverted intuitive (ENFP and ENTP) types as compared with a matched group of non-volunteers. The rationale for such a choice was based on the following sketch of a "typical volunteer personality":

direct responsiveness to others and an intrinsic enjoyment of interpersonal relationships; an empathic, nonjudging attitude toward others; and sufficient optimism about the possibilities for growth, and about one's possible effectiveness as an instrument of change, to support the volunteer through difficult times. 49

Ten volunteers in a halfway house for disturbed adolescents in Washington, D. C. and a matched sample were given the MBTI. Seven of the ten volunteers were extraverted intuitive types (EN). Two of the three remaining volunteers had marginal scores on the ExtraversionIntroversion index. The ten non-volunteers were distributed over seven type categories. The Carlson study findings were compared to a study by Mary McCauTey (1972), who found extraverted intuitive types predominately represented by volunteers in a crisis center. 50 
Another study, also cited by Carlson and Levy, was that work done by Mosher, Teitman, and Mann (1972).51 This investigation identified volunteer staff members of a paraprofessional treatment program for schizophrenics to be NFP types with a combination of Extraverted and Introverted attitudes.

\section{Reliability and Validity Studies}

A number of studies involving the use of the MBTI have been directed toward determining the reliability of the Indicator. The manual presents the split-half reliabilities of the Indices for various groups, including males and females from a wide range of age, intellectual ability and socio-economic status. Each index was split in half and correlations were obtained between the halves. The only co-efficients below .75 are attributed to the underachieving 8th grade and the non-prep 12th grade, with the lowest values indicated for the TF index. The highest value was obtained by National Merit Finalists. 52 These particular results indicate the importance of the influence of understanding, vocabulary, motivation, and maturity on the reliability of test scores. The TF index appears to be the weakest of the indices over all of the samples taken, except those of the college age group. Myers makes the assumption that since Brown and Pembroke students scored in the $.80^{\prime} \mathrm{s}$ for $T F$, that the development of judgement ( $T$ or $F$ ) "is one of the slowest and most reluctant achievements in the process of growing up." 53

Since the overall range of split-half measures is between the 
high $.70^{\prime} \mathrm{s}$ and $.80^{\prime} \mathrm{s}$ on the continuous scores, the MBTI appears to be comparable to other leading personality inventories.

Lawrence Striker and John Ross have done a number of studies, one of which involved a 14 month test-retest use of the MBTI, which indicated correlations at the .70 leve1 for EI, SN, and JP indices, and a .48 correlation for the TF index. ${ }^{54}$

Another Striker and Ross study assesses validity by correlating scales with ability, interest and personality scales and differences on scales between sexes and between students in different high school programs. This study criticizes the indices finding them somewhat restrictive compared to their intended definition. ${ }^{55}$

The Buro's Personality Tests and Reviews records a test critique by Gerald A. Mendelsohn, Assistant Professor of Psychology at the University of California at Berkeley, who identifies the MBTI as having potential in the area of personality research and academic counseling. He takes issue with the test's definition of the IE index and feels that it measures Introversion and Extraversion more in the popular sense than in the way defined by Jung. He also indicated that continuous scores are too vulnerable to the reliability of the individual test taker. He states that it is "risky to infer basic personality differences when the omission or change of a single item could alter a subject's classification." 56

Another Buro's reviewer, Norman D. Sundberg ${ }^{57}$ cautions the use of the MBTI with younger groups, stating that reliability of scores increases with age and maturity. This appears to be substantiated 
by the MBTI Manual's low correlates for younger Junior High School students. He also states that borderline scores (those with very little difference between opposites) are less reliable as a clear statement of type preference. ${ }^{58}$

In 1965 John R. Braun attempted to test the validity of scores in the case that subjects might "fake" their responses. Subjects were asked to take the MBTI with the regular instructions and then, again later, with the additional request of giving answers that would result in giving others a favorable impression of them. Braun's findings pointed to the possibility that faked responses led to greater preferences for $E, S, T$, and $J$ types. ${ }^{59}$

Despite these warnings in the use of the MBTI, many reviewers, including Sundberg feel that the MBTI with its present limitations is one of the only indicators that addresses personality type issues in terms of the theory of personality typology. Sundberg focuses on the similarity of types in areas of relationship compatibility and finds the MBTI helpfur in making such identifications. He also states, "for certain tasks to be accomplished, it would be necessary to have different types (as tested by the MBTI) represented."60

\section{Baker-Schulberg Community Mental Health Inventory (CMHI)}

1. Description

The CMHI is an instrument of 38 items designed for use with mental health professionals. To ensure that major aspects of community mental health ideology were covered, the following five major 
conceptual categories were employed:

1. Population focus

2. Primary prevention

3. Social treatment goals

4. Comprehensive continuity of care

5. Total community involvement

The CMHI is a multiple choice paper and pencil test, designed to measure an individual's degree of adherence to Community Mental Health ideology. Each individual was asked to indicate how strongly he identified with different intervention orientations on a continuum ranging from strongly, moderately, or slightly agree to slightly, moderately, or strongly disagree. Scoring of the test is done by hand with a numerical score obtained.

Low scores on the CMHI indicate orientations toward treatment and individual intervention. High scores indicate orientations toward planning and administration.

\section{Reliability and Validity Studies}

The first version of the scale consisted of 88 questions, submitted to a nationwide panel of 16 prominent leaders in various mental health disciplines. After obtaining the results and suggestions of these "judges", 64 items were constructed with a 6-point Likerttype rating form. This was distributed to 484 persons from nine professional organizations, representing broad variations in mental health orientations. The following nine groups were studied: 
1. Harvard Post-Doctorals

2. Harvard Visiting Faculty

3. Community Psychologists

4. Columbia Post Doctorals

5. American Psychological Association

6. American Occupational Therapy Association

7. Society for Biological Psychiatry

8. American Psychiatric Association

9. American Psychoanalytic Association

The final version, containing 38 items were obtained on the basis of item total correlations (.44 or higher) and factor analysis (which supported the item total correlations.) 61

of the 38 items, 19 were positively oriented and 19 negatively oriented toward Community Mental Health principles and beliefs. Reliabilities of the final scale range from .92 to .95 . Validity was assessed by studying various aspects of the scale. 62

First of al1, the means, standard deviations, and ranges for the nine groups described earlier were determined. The results, especially mean scores are highly significant to the present study. A clear ordering of interest groups appears and is described in Table II ${ }^{63}$ which is taken from the Baker-Schulberg CMHI Scale Manual. As can be seen, the four groups with a public commitment to community mental health have the highest means. The means of the other professional associations follow with psychoanalysts receiving the lowest mean scores. Another study compared the scores of the nine groups with individual self-ratings of four psychiatric orientations: somatic (organic), psychotherapeutic, sociotherapeutic (milieu), and community mental health. Results showed that the total score on the CMHI Scale was significantly correlated $(r=.55, p<.001)$ with self-rated iden- 
tification with a community mental health orientation. The scale was also highly correlated to the sociotherapeutic orientation $(r=.41$, $p<.001) .64$

\section{TABLE II}

BASIC CMHI SCALE DATA FOR CRITERION GROUPS

Group

Doctorals

Harvard Visiting

Faculty

Community

Psychologists

Columbia Post-

Doctorals

Amer. Psychol.

Assoc. (Div.

12)

79

23

25

Mean

Score

239.79

19.48

$165-262$

15

234.60

26.91

$160-264$

234.43

14.68

$195-264$

221.96

24.06

$173-260$

Amer. Occup.

Therapy

Assoc.

35

207.69

21.07

$161-243$

Soc. for Biol.

Psychiat.

29

206.28

32.97

$137-258$

Amer. Psychiat.

Assoc.

175

198.93

37.02

$92-265$

Amer.

Psychoanal.

Assoc.
46
194.52

37.23

$125-259$ 
scorers to individuals interested in keeping up with the current trends and developments of the field. High scorers tended to be more interested in community mental health, culture and personality, social psychiatry, epidemiology, group psychotherapy and milieu therapy. The low scorers appeared to follow the fields of individual psychotherapy, biochemistry, genetics, neurology and neuropharmacology. 65

A similar comparison was made of high and low scorers with regard to preference for specific symposium topics on recent advances in: community mental health, milieu therapy, psychotherapy, and somatic therapy. The highest scoring quartile preferred the topics related to community mental health, then milieu therapy, psychotherapy and then somatic therapy. The lower scoring quartile preferred the topics of psychotherapy, then community mental health, with the others receiving the lowest ranking. 66

Baker and Schulberg, in their initial article discussing the CMHI Scale, state that the 19 seven-point, bipolar adjective rating scale showed a significant difference in high and low scores at the .001 level of significance. High scorers defined the meaning of community mental health as "good, effective, relevant, timely, new, progressive, wise, complex, right, sophisticated, broad, considered, realistic, needed, important, strong, productive, cooperative, and active." 67 Low scorers, on the other hand were less positive about community mental health, rating it less active and potent. ${ }^{68}$

High and low scoring respondents to the initial 9 group study differed significantiy in the type of work in which the individuals 
were engaged. The higher scoring group chose work in universities and medical schools, general hospitals, community clinics, and school systems, while the lower scoring group was found to be predominately employed in mental hospitals and private clinical practice. Respondents in the higher scoring quartile appear to spend a greater part of their employment in administration, consulting and teaching. The lowest quartile on the other hand spent more of their work week in direct patient treatment. 69

Another indication of the test results appears to point to a possible age variable. Younger respondents tended to be more supportive of community mental health concepts. There also was a significant correlation between high scorers and a recent date of an advanced training degree. 70

Robert Fitzpatrick, the Principal Research Scientist for the American Institutes for Research in Pittsburgh, Pennsylvania reported criticism of the method chosen to pick a random sample in each of the 9 groups studied. He also pointed to the importance of using the CMHI Scale only with groups familiar with mental health concepts and language. He stated in conclusion that "reliability is adequate and a reasonable degree of content and construct validity has been demonstrated." 71 Lester M. Libo from the University of New Mexico reviewed the scale, concluding that "the authors have done a creditable job in constructing and assessing a relevant and useful scale." He also felt that "the CMHI is a valuable contribution to the advancement of research in community mental health. "72 


\section{Additional Studies}

In 1971, Paul Morris Pantleo ${ }^{73}$ completed a doctoral dissertation studying Community Mental Health Ideology. Three areas were investigated: 1) an examination of the community mental health ideology of the staff of comprehensive mental health centers and a more traditional mental health facility (Veterans Administration Hospital), 2) an assessment of the relationship between community mental health ideology and employment experience, demographic variables, and career commitment, and 3) an exploration of the conmunity mental health movement. Using the CMHI Scale, the study identified social workers as more highly advocating the community mental health "movement". Years of employment and age/education also revealed similar influences to those in earlier studies.

In another study involving the use of the CMHI Scale, Robert $D$. Langston, Ph.D. 74 found significant relationships between scores, professional affiliation, years of liberal arts education and the length of time working in a community mental health center. The subjects of this study were employees of two community mental health centers in Houston, Texas. Means, standard deviations and ranges of the professional groups were determined. See Table III. ${ }^{75}$ The Langston findings substantiated earlier test results of social workers. This group obtained higher scores than any other group. Explanation for this trend is seen by the authors to be a function of social work training which focuses more on the community as a whole with a broader utilization of services than other groups such as the 
psychiatric group which tends to have a more "individual" focus . Though the findings reported by this study are significant only to the professional groups in this particular setting, the study is important for its comparison of social workers to other professional groups in its adherence to community mental health ideology.

\section{Demographic Sheet}

A data sheet was constructed to provide pertinent descriptive data about the respondents for this study. Indices included age, sex, previous social service related employment or volunteer positions, and a five year projection of an "ideal" employment position (See Appendix Number 1).

TABLE III

CMHI scale data for professional groups

\begin{tabular}{llll} 
Group & Mean Score & S.D. & Range \\
\hline Psychiatry & 202.38 & 19.84 & $171-236$ \\
Psychology & 229.00 & 20.36 & $185-248$ \\
Social work & 235.89 & 16.41 & $200-257$ \\
OT-RT & 273.65 & 16.82 & $180-255$ \\
Nursing & 210.23 & 20.17 & $180-246$ \\
LVN, Aide, Orderly & 180.02 & 25.46 & $129-244$ \\
Secretary & 205.14 & 23.48 & $165-232$
\end{tabular}

Field Preference Questionnaire

Later in the study a single item, multipie choice question was constructed to force a respondent's choice of "ideal" social work position employing $80 \%$ of his or her job time. Five choices were 
presented which represented a continuum of practice areas from individually oriented practice to radical social work practice. For the purposes of discussion in this study, the five areas (See appendix Number 2) of field practice will be identified as follows:

1. Interpersonal and Intrapsychic Intervention.

2. Problem Oriented Intervention.

3. Community Mental Health.

4. Planning and Administration (including program evaluation).

5. Radical Social Work 


\section{CHAPTER V}

\section{PROCEDURE}

The following materials were distributed on February 1, 1978, to the remaining enrolled 68 second year graduate students at Portland State University:

1. Myers-Briggs Type Indicator (MBTI) Form $\mathrm{F}$

2. Baker-Schulberg Community Mental Health Inventory (CMHI)

3. Demographic Data Sheet

A letter accompanied this material informing students of the general purpose of the study and instructing them how to return the materials (see Appendix Number 3 ). Students were also told that they could include their names on the demographic sheet if they were interested in receiving their test profiles. It was hoped this might be an incentive for a high return rate on the test packets. All materials were number coded and delivered to the student boxes in plain manilla envelopes. A box was provided in the student lounge for respondents to place finished materials.

A second follow-up letter was sent out three (3) weeks later (see Appendix Number 4). At the end of Winter Term, a personal plea was made in three of the four second year theory classes for return of the materials by finals week.

Thirty-six packets were returned and graded by March 20, 1978. As this constituted only a little over $50 \%$, new packets with a new 
cover letter were distributed on Apri1 3, 1978, to those not originally responding (See Appendix Number 5). Five names were chosen at random from the non-respondents. Personal contact was made with the individuals chosen in order to ensure a random sample of initial nonrespondents.

At this time the data sheet was amended to replace question number four. This question addressed the respondents five year projection of an "ideal" employment position. As most initial answers were sketchy, including many "I don't know" responses, it was decided to use a more comparable tool for measurement. A single, multiple choice, question was constructed, dividing employment practices into five (5) separate areas. Respondents were requested to check one of the field areas as their personal preference or write in a preference (where not already identified) under the category most similar to the preferred position. This Field Preference Questionnaire was distributed with a cover letter (See Appendix Number 6) to the entire population.

A total of 41 packets were returned by the second collection on April 15, 1978, with an additional return of 2 out of the 5 randomly chosen samples (chosen to represent the remaining non-respondents). The total of 43 returns constituted a return rate of 63 percent overa 11. Due to the fact that only two of the 5 randomly chosen samples responded, any conclusions based on projecting the response of those not cooperating in this study would involve a bias interval of 18.4 . 
A11 of the respondents who answered the original data sheet question involving "ideal" social work employment with "I don't know" responses returned the Field Preference Questionnaire. Of the 43 respondents, 9 did not return the Field Preference Questionnaire but had described "ideal" employment on the original data sheet in enough detail to be easily identified in one of the 5 categories. 


\section{CHAPTER VI}

\section{FINDINGS}

In comparison with prior CMHI studies of social work employees, it was interesting to note that the subjects in the present investigation had a mean score of 225.65. This score falls in a midpoint between the Columbia Post Doctorals and Community Psychologists in Baker's original testing of the scale among the nine criterion groups (which excluded social workers). Langston's mean of 235.89 for social workers, reported earlier in this study, focused on employees of community mental health centers and thus suggests that a higher score was received by that group due to work emphasis on community mental heal th ideology. The students in the present study indicated job preferences in widely diverse areas, including those in other than community mental health center settings.

The standard deviation in scores of this population is quite large (25.77), spreading $68.2 \%$ of the scores between 199.88 and 251.42. Since the overall range in scores varied between 160 and 261 , the standard deviation indicates that scores differed quite widely on an individual basis. The hypothesis that introverts would score lower than extraverts on the CMHI was not substantiated by this study. Introverts covered the entire range of scores from 160 to 261 , with extraverts covering a somewhat smaller, though not remarkable different range from 190 to 253. Introverts with a mean score of 223.80 
$(S D=27.35)$ on the CMHI and Extraverts with a mean of 228.75

$(S D=21.60)$ come very close to being alike. When a correlation coefficient was figured for the two variables (MBTI continuous scores for Introversion/Extraversion and CMHI scores) a correlation of -0.22725 was obtained, showing a slight, indirect relationship between the two.

A breakdown by age and sex in Tables IV and $V$ appear to give no further leads as to factors determining a high or low score on the CMHI.

TABLE IV

AGE AS COMPARED TO CMHI SCORES

\begin{tabular}{lccc}
\hline Age & Frequency & Percent & Mean Score \\
\hline $23-30$ & 28 & 65 & 227.82 \\
$31-38$ & 9 & 21 & 275.55 \\
$39+$ & 6 & 14 & 230.66 \\
\hline
\end{tabular}

TABLE V

SEX COMPARED TO CMHI SCORES

Sex

Frequency

Percent

Mean Score

Male

13

Female

30

30

70

224.38

226.20

The results of the CMHI were also compared with the Field Preference Questionnaire to test the conclusions presented in the Baker- 
Schulberg Manual which state that high and low scores represent differences in ideology and in work preference. As stated previously in this study, the nine criterion groups tested to establish reliability of the CMHI showed that the lowest quartile spent their work week in direct service with clients in such settings as mental hospitals and private clinics, whereas the highest quartile spent most of their time in administration, consultation, and teaching in university, medical school, general hospital, community clinic, and school system settings. The Field Preference Questionnaire, as designed for this study, categorizes field and work settings into 5 distinct groups (See Appendix Number 2 for definitions). Though the questionnaire cannot be truly identified as a scale of 1 through 5,1 being low and 5 being high, the five (5) separate categories are numbered and listed in such a way as to describe a preference for work as follows:

1. Interpersonal and Intrapsychic Intervention

2. Problem oriented Intervention

3. Community Mental Health (as defined by Bloom) 76

4. Administration and Planning (including program evaluation)

5. Radical Social Work

Four of the categories, excluding Radical Social Work, are described similarly in the Baker-Schulberg Manual with employment preferences of the 1 and 2 types identified with low scores and preferences of the 3 and 4 types having higher scores. Comparing the results of this questionnaire to the Baker-Schulberg CMHI, it was hoped that it might be possible to substantiate the findings of Baker-Schulberg and also 
identify a range of adherence to community mental health ideology among these identified preferences for social work practice. Table VI describes the results.

\section{TABLE VI}

COMPARISON OF THE RANGES OF CMHI TO WORK PREFERENCE

\begin{tabular}{lccccc}
\hline & 1 & 2 & 3 & 4 & 5 \\
\hline $\begin{array}{l}160-193 \\
194-227\end{array}$ & 2 & 1 & 1 & 9 & 0 \\
$228-261$ & 2 & 8 & 1 & 7 & 2 \\
\hline \hline $\begin{array}{l}\text { Tota 1s } \\
\text { Percent }\end{array}$ & 3 & 7 & 7 & 3 & 5 \\
\hline \hline $\begin{array}{l}\text { Mean } \\
\text { Standard } \\
\text { Deviation }\end{array}$ & 7 & 16 & 9 & 4 & 7 \\
\hline
\end{tabular}

Results show that in terms of mean scores for the group, an increase in mean score appears steady between category 1 and category 4 . Category 5, defined as Radical Social Work, appears to be situated on a midrange between category 3 and category 4 . As this category was added by the authors as pertaining exclusively to the social work profession and since it is not addressed in any way by the BakerSchulberg Manual, we believe it is correct to delete this category and still report a similar trend in low and high scores as described by Baker-Schulberg. An analysis of variance provides a $F$ Ratio of 1.1508 between the groups. It was not significant at the .05 level 
with 4,38 degrees of freedom. Though the lack of correlation between the CMHI and MBTI provide this study with insignificant results, the MBTI scores for the group studied appear to provide some additional indications about the personality types of the subjects tested.

Results of the Myers-Briggs can be presented in a number of different ways. Continuous scores are computed for each of the indices and a personality type is identified. The following is a list of all possible combinations:

$\begin{array}{llll}\text { ISTJ } & \text { INTJ } & \text { ESTJ } & \text { ENTJ } \\ \text { ISTP } & \text { INTP } & \text { ESTP } & \text { ENTP } \\ \text { ISFJ } & \text { INFJ } & \text { ESFJ } & \text { ENFJ } \\ \text { ISFP } & \text { INFP } & \text { ESFP } & \text { ENFP* }\end{array}$

In reading the results of extraverts, the last indice Judgement or Perception indicates whether the judging (Thinking or Feeling) or perceptive (Intuition or Sensation) process is dominant. Both processes are used by the individual, but the dominant process in the extravert is used primarily as he deals with his external environment, leaving his auxiliary function to deal with his internal 1 ife. Therefore, the ENTP type is predominately on intuitive type, using intuition in his external world where he functions best. The ENTJ

$$
\begin{aligned}
{ }^{*} I & =\text { Introversion } \\
E & =\text { Extraversion } \\
T & =\text { Thinking } \\
F & =\text { Feeling }
\end{aligned}
$$

$$
\begin{aligned}
& S=\text { Sensation } \\
& N=\text { Intuition } \\
& J=\text { Judgement } \\
& P=\text { Perception }
\end{aligned}
$$


type, on the other hand, is primarily a thinking type, using this as his dominant function.

The introvert, as opposed to the extravert, prefers the internal world which is the field to which he is best oriented. Thus, his dominant function is used primarily in his internal world, where his auxiliary function is seen more by those with whom he makes contact in his external environment. The INTP type, then, is basically an intuitive type, but he uses thinking in his external environment. The INTJ is opposite, having thinking as the dominant function and operating with intuition in his external world. 77

Assuming that the $J$ or $P$ process is encountered in conflicts between individuals arguing such philosophies as those studied in this investigation, the type of process identified in the following findings will be that which operates in the individual's external environment (the dominant function in the extravert, the auxiliary function in the introvert).

As a group, Introverts (27) accounted for $63 \%$ of those studied, whereas Extraverts (16) made up 37\%. As an external environment function, the group fell into the following categories:

Intuitives (19)

Feeling (15)

Thinking (6)

Sensation (3)
$44 \%$

$35 \%$

$14 \%$

$7 \%$

As it can be seen, Intuitive and Feeling types account for $79 \%$ of those tested, making a much clearer statement about the social 
work students as a whole than the indice of Introversion or Extraversion. This indication matches closely suitable employment areas as suggested by the Myers-Briggs Manual and listed here in this study in Table I. As previously described, Yura's identification of $F$, Carlson and McCauley's identification of N, and Moser's identification of NF types lend support to the assumption that counselors, psychology students, volunteers in halfway houses and crisis centers, and social workers draw heavily on $F, N$, or NF types to fill the ranks of such helping professions. Table VII groups the MBTI types in this study according to their within group mean and lists the types in a range of high to low for CMHI means.

\section{TABLE VII}

COMPARISON OF MBTI TYPES AND CMHI MEAN SCORES

TYPE NUMBER FREQUENCY

MEAN CMHI

\begin{tabular}{lccc}
\hline ET & 2 & 4.65 & 247.00 \\
IN & 11 & 25.58 & 237.27 \\
EN & 8 & 18.61 & 235.13 \\
IF & 9 & 20.93 & 215.45 \\
IT & 4 & 9.30 & 215.00 \\
EF & 6 & 13.95 & 217.50 \\
IS & 3 & 6.98 & 211.33 \\
\hline TOTALS & 43 & 100.00 &.-- \\
CMHI Population Mean & - &.--65 \\
\hline
\end{tabular}


Table VII shows that feeling types make up the majority of mean scores lower than the population mean and that intuitives make up nearly all the mean scores higher than the population mean. The sensation types have the lowest mean by category, while ET types have the highest mean by category. This table suggests, that should the findings reported by Baker-Schulberg for their nine criterion groups hold true for other groups tested, the ET types might reflect a personality factor with scores in the range of administrative and planning types. This outcome is similar to that of Terrill, previously mentioned, who found that administrative types preferred thinking as opposed to counselors who preferred the feeling mode of expression. Although less clearly delineated by the data, there is some possibility that EF and IF types are more likely to score lower on the CMHI and have a greater interest in direct patient care, whereas IN and EN types may be more likely to endorse community mental health ideology. Though the indication is only suggested, the predominance of Thinking, Feeling, Intuition, or Sensation may be more indicative of whether social workers see individuals or society as the focus of social work practice than Introversion and Extraversion.

\section{Summary}

Findings in this study indicate the following information about the second year graduate social work students studied:

1. Social work students score high on the Community Mental Health Inventory Scale as compared to other mental health professionals previousiy tested. 
2. There appears to be no correlation between introverts and low scores on the CMHI (indicating preference of direct service to clients), nor a correlation between extraverts and high scores on the CMHI (indicating adherence to community mental health ideology, administration, consultation, planning, and possibly more radical philosophies promoting societal change).

3. Age and sex appear to have no influence on high and low scores on the CMHI.

4. The comparison of the CMHI and the Field Preference Questionnaire indicates a suggested increase in CMHI mean scores for work preference categories as the student becomes less client focused. The difference between the groups was not significant.

5. Intuitive and Feeling types make up $79 \%$ of those studied.

6. Extraverted Thinking (ET) types scored the highest CMHI mean, while Extraverted Feeling (EF) and Introverted Feeling (IF) types scored CMHI means somewhat higher than did Extraverted Intuitive (EN) and Introverted Intuitive (IN) types. Introverted Sensation (IS) types appeared to score the lowest mean of all groups with no representation of Extraverted Sensation (ES) types at all. 


\section{CHAPTER VII}

\section{DISCUSSION}

The Taber and Vatanno study $(1968)^{78}$ explored whether or not the "clinical" vs. "social" dilemma was indeed a reality in the field of social work practice. They hypothesized that those social workers who endorse the more clinical approach to clients would then not endorse social intervention. They found conversely that respondents most frequently supported both aspects of social work intervention. This study might shed light on some of the factors that were operant in our investigation. Our study shows that social work students tend to predominately use feeling and intuition as they deal with their external environment. When using the feeling attitude to come to a conclusion about a problem, other possibilities have to be shut off temporarily. To quote Isabel Myers, "The evidence is all in. Anything more is incompetent, irrelevant and immaterial. One now arrives at a verdict and gets things settled." 79

When using intuition one sees all the possibilities in a given situation. Focusing on these attributes, then, it might be possible to see a connection between the current conflict and the way in which intuitive and feeling types interact with one another. The preference of a feeling type to identify an answer as "right", "good" and "positive" as opposed to another which would be seen as "wrong", "bad" and "negative", and the ability of the intuitive to carry an issue 
into all of its possible ramifications, might set either of the types at odds.

Yet it appears that, specific issues aside, in the general practice of social work, a clinically oriented social worker, focusing on the individual client, might also take into consideration social and environmental factors. He or she might be able to endorse and support social change issues introduced by those who enthusiastically work for social and political change. The social change agent, on the other hand, though not intimately involved in individual treatment, might employ those qualities that characterize good social casework in his or her empathic and caring attitude towards the individuals who make up the society he or she so wishes to improve. The socially conscious social worker might, therefore, endorse many of the helping techniques used by his clinical colleague.

The outward appearance of conflict, then, might not be a matter of such diametricaliy opposed philosophies about the broad base of social work interventions, but rather be a function of the argumentative nature of the personality types that characterize social workers. As a result, the constant fight over situational approaches make it appear that social workers are a dichotomous group. Yet in actuality they deny, as the Taber and Vattano study seems to indicate, such a rigid either/or approach to helping, and for the most part, agree with the original tenants of casework as Mary Richmond set them out. 


\section{CHAPTER VIII}

\section{RECOMMENDATIONS}

The suggested implications of the present investigation leaye at least two major areas for further exploration. Additional CMHI testing of social workers employed in various settings might give a clearer indication of the profession's endorsement of community mental health ideology. A more important implication that Intuitive and Feeling types characterize the majority of social work professionals might be an interesting avenue for further research. Since this study was not able to clearly implicate Introversion and Extraversion as having an influence on the conflicts between social workers, it remains to be determined if other personality factors might have a more important impact on this interaction process. 


\section{FOOTNOTES}

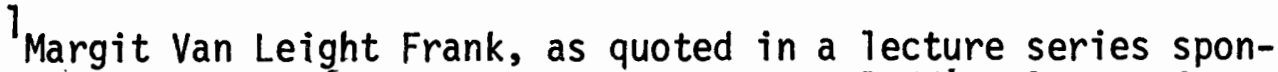
sored by Centerpoint (St. Louis: Centerpoint, 1977), Chapter 4, Part B, p. 3 .

Ibid.

3 Ibid.

${ }^{4}$ Mary E. Richmond, What Is Social Case Work? (New York: Russe11 Sage Foundation, 1922), p. 259.

${ }^{5}$ Clarke A. Chambers, Seedtime of Reform (Minneapolis: University of Minnesota Press, T963), p. 89.

6roy Lubove, The Professional Altruist (New York: Atheneum, 1971), p. 81 .

${ }^{7}$ Roy Lubove, pp. 107-108.

${ }^{8}$ Chambers, p. 89.

9 porter R. Lee, Social Work as Cause and Function and 0ther Papers (New York: Columbia University Press, 1937), p. 3.

10Lee, pp. 3-4.

$11_{\text {Lee, }}$ p. 8.

${ }^{12}$ Lee, p. 9.

${ }^{13}$ Lubove, Op. Cit., p. 86.

14Ernest V. Hollis and Alice L. Taylor, Social Work Education in the United States (New York: Columbia University Press, 1951), p. 142.

15 Helen Harris Perlman, "Free Association on Problems of Child Welfare: Putting the Social Back in Social Casework, "Child Welfare, 31 (JuTy, 1952), 8-9.

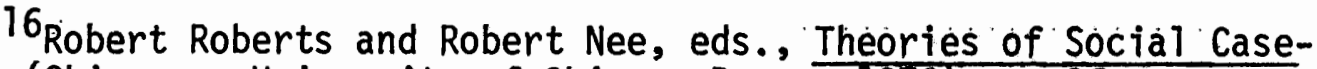
work (Chicago: University of Chicago Press, 1970), p. 36. 
17 Merlin A. Taber and Anthony J. Vattano, "Clinical and Social Orientations in Social Work: An Empirical Study," Social Service Review, (1970), Vol. 44, 34-43.

${ }^{18}$ Eveline Burns, "Tomorrow's Social Needs and Social Work Education." Journal of Education for Social Work, 2, No. 1 (Spring 1966), as quoted in William Schwartz, "Private Troubles and Public Issues: One Job or Two," Lecture at the National Conference on. Social Welfare, May 28, 1969.

19 William Schwartz, "private Troubles and Pub1ic Issues: One Job or Two," Lecture at the National Conference on Social Welfare, May 28, 1969.

${ }^{20}$ Alfred J. Kahn, "The Societal Context of Social Work Practice," Social Work, 10 (October 1965), 149.

$21_{\text {Lee, }}$ p. 23.

${ }^{22}$ Carl G. Jung, Psychological Types (1921 rpt. Princeton: Princeton University Press, 1971).

${ }^{23} \mathrm{~N}$. Tranel, "Effects of Perceptual Isolation on Introverts and Extraverts," Psychiatric Research, 1 (1962), 185-192.

${ }^{24}$ Ascanio M. Rossi and Philip Solomon, "Note on Reactions of Extraverts and Introverts to Sensory Deprivation, "Perceptual and Motor Skills, 20 (1965), 1183.

${ }^{25}$ T. L. Veach and J. C. Toukey, "Personality Correlates of ACcurate Time Perception," Perception and Motor Ski11s, 33 (1971), 765-766.

${ }^{26}$ Lester Mann, "The Relation of Rorschach Indices of Extratension and Introversion to a Measure of Responsiveness to the Immediate Environment," Journal of Consulting Psychology, 20, No. 2 (1956), 114-118.

27 Kenneth J. Shapiro and Irving E. Alexander, "ExtraversionIntroversion, Affiliation, and Anxiety," Journal of Personality, 37 (1969), 387-406.

${ }^{28}$ Isabel Briggs Myers, The Myers-Briggs Type Indicator Manual, (Pa10 A1to: Consulting Psychologists Press, 1962), p. 1.

29 Myers, p. 51 .

30 Myers, p. 58. 
$31_{\text {Myers, p. } 4 .}$

32 Myers, p. 56.

33Harold W. Grant, Behavior of MBTI Types, (Auburn: Research Report, Student Counseling Service, Auburn University, 1965), p. 5.

${ }^{34}$ Harold W. Grant, Comparability of Gray-Wheelwright Psychological Type Indicator and the Myers-Briggs Type Indicator, (Auburn: Research Report, Student Counseling Service, Auburn University, 1965), p. 2 .

${ }^{35}$ Myers, Op. Cit., pp. 23-35.

${ }^{36}$ David 0. Hill, Extraversion-Introversion: 'An Investigation of Typological Theory, (Lubbock, Texas: Dissertation Abstracts International, 1970), 31, p. 6257B.

${ }^{37}$ Richard Vance Peavy, Ed.D., A Study of Jung's Concepts of Intuitive Perception and the Intuitive Type, (Eugene, Oregon: Dissertation Abstracts, 1963), 24, p. 4551.

38 Marce1 L. Goldschmid, "Prediction of College Majors by Personality Tests," Journal of Counseling Psychology, 14, No. 4 (1967), 302-308.

${ }^{39}$ Sylvia Lynn Stroops, Personality Types and Vocational Interests of Female Students Majoring in Two Different Areas of Teacher Education, (Alabama: Dissertation Abstracts, 1971), 32, p. 5027A.

40

Thomas Charles McNamara, A Study of Philosophical Identities in a Counseling Practicum, (Urbana: Dissertation Abstracts, 1967), 28, p. 4878A.

41

Ibid.

42Jerry Lee Terri17, Correlates of Counselor Role Perception, (Boulder: Dissertation Abstracts, 1969), 31, p. 166A.

${ }^{43}$ Ibje.

${ }^{44}$ Michael T. Yura, Ph.D., The Personality Traits and Vocational Interests of Guidance Students, Columbus: Dissertation Abstracts Internationa7, 1971), 32, p. 3711 A.

${ }^{45}$ Rae Carlson and Nissim Levy, "Brief Method for Assessing Social-Personal Orientation," Psychological Reports, 23, (1968), 911914.

${ }^{46}$ Carlson, p. 911. 
${ }^{47}$ Carlson, p. 912.

${ }^{48}$ Rae Carlson and Nissim Levy, "Studies of Jungian Typology," Journàl of Personality, 41 (December 1973), p. 563.

49 Ibid.

50 Ibid.

51 Ibid.

52 Myers, Op. Cit., p. 20a.

53 Ibid.

${ }^{54}$ Lawrence J. Stricker and John Ross, "Some Correlates of a Jungian Personality Inventory," Psychological Reports, 14 (April 1964), 623-643.

55 Lawrence J. Stricker and John Ross, "Intercorrelations and Reliability of the Myers-Briggs Type Indicator Scales," Psychological Reports, 12, No. 1 (1963), 287-293.

${ }^{56}$ 0scar Krison Buros, Personality Tests and Reviews, (Highland Park New Jersey: Gryphon, 1970), p. 322.

57 Buros, p. 321.

58 Buros, p. 323.

${ }^{59}$ John R. Braun, "Note on a Faking Study with the Myers-Briggs Type Indicator," Psychological Reports, 17 (1965), 924.

60 Buros, Op. Cit., p. 321.

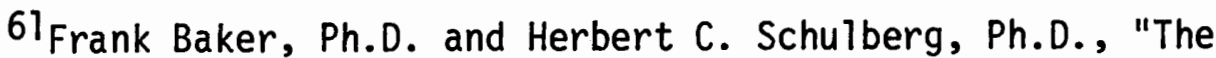
Development of a Community Mental Health Ideology, "Community Mental Health Journal, 3, No. 3 (Fall 1967), 218.

62 Baker, p. 221.

63 Ibid.

64 Baker, p. 222.

${ }^{65}$ Oscar Krisen Buros, Seventh Mentà Measurements Yearbook, (Highland Park: Gryphon, 1938), p. 4T.

$66_{\text {Baker, pp. 222-223. }}$ 
67 Baker, p. 223.

${ }^{68}$ Ibid.

69

Ibid.

70 Baker, p. 224.

71 Buros, p. 40.

72 Ibid.

73 Paul Morris Pantleo, Ph.D., Community Mental Health Ideology: An Analys is of Community Oriented and Traditional Mental Health Facilities, (Boulder: Dissertations Abstracts Internationa1, 1971), 33, p. 447B.

${ }^{74}$ Robert D. Langston, "Community Mental Health Centers and Community Mental Health Ideology," Community Mental Heal th Journal, 6, No. 5 (October 1970), 388.

75 Langston, p. 391.

76Bernard L. Bloom, Community Mental Health: A General Introduction, (Monterey, California: Brooks/Cole Publishing Company, 1977), pp. T-5.

77 Myers, Op. Cit., p. 59-61.

78 Taber and Vattano, Op. Cit., pp. 34-43.

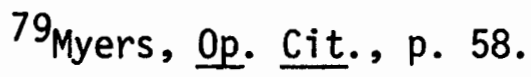




\section{A LIST OF WORKS CONSULTED}

Baker, Frank, Ph.D. and Herbert C. Schulberg, Ph.D. "The Development of a Community Mental Health Ideology Scale." Community Mental Hea] th Journal, 3 (1967), 216-225.

Bennett, Ivey V. "A Plea for Personality Theory." Social Work, 31 (1975), 7-10.

Bloom, Bernard L., Community Menta] Health: A General Introduction. Monterey, California: Brooks/Cole Publishing Company, 1977.

Bradway, Katherine. "Jung's Psychological Types." Journal of Analytical Psychology, 29 (1949), 189-200.

Braun, John R. "Note on a Faking Study with the Myers-Briggs Type Indicator." Psychological Reports, 17 (1965), 924.

Burns, Eveline. "Tomorrow's Social Needs and Social Work Education." Journal of Education for Social Work, 2 (1966), 141-155.

Buros, 0. Personality Tests and Reviews. Highland: Gryphon, 1970.

Buros, 0. Seventh Mental Measurements. Highland: Gryphon, 1938.

Carlson, Rae and Nissim Levy. "Brief Method for Assessing SocialPersonal Orientations." Psychological Reports, 23 (1968), 911-914.

Carlson, Rae and Nissim Levy. "Studies of Jungian Typology." Journal of Personality, 41 (December 1973), 559-576.

Carrigan, Patricia H. "Extraversion-Introversion as a Dimension of Personality: A Reappraisal." Psychological Bulletin, 57 (1960), 329-360.

Chambers, Clarke A. A Historical Perspective on Political Action vs. Individualized Treatment. New York: Council on Social Work Education, 1962.

Chambers, Clarke A. Seedtime of Reform: American Social Service and Social Action 1918-1933. Minneapolis: University of Minnesota Press, 1963.

Danstedt, Rudolph T. Political Action vs. Individualized Treatment in Social Welfare Work. New York: Council on Social Work Education, 1962. 
Frank, Margit Van Leight. Series of Lectures presented by Centerpoint. St. Louis: Centerpoint, 1977.

Goldenberg, I. Ira. The Helping Professions in the World of Action. Lexington: Lexington Books, 1973.

Goldschmid, Marcel L. "Prediction of College Majors by Personality Tests." Journal of Consulting Psychology, 14 (1967), 302-308.

Grant, W. Harold. Comparability of the Gray-Wheelwright Psychological Type Indicator and the Myers-Briggs Type Indicator. Auburn, Alabama: A Doctoral Dissertation, Auburn University, 1965.

Grant, W. Harold. Behavior of MBTI Types. Auburn, Alabama: A Doctoral Dissertation, University of Auburn, 1965.

Gray, Horace, M.D. "Jung's Psychological Types in Men and Women." Stanford Medical Bulletin, 6 (1948), 29-36.

Gray, Horace, M.D. "Jung's Psychological Types: Ambiguous Scores and Their Interpretation." Journal of General Psychology, 40 (1946), 63-88.

Gray, Horace, M.D. "Psychological Types in Married People." Journal of Social Psychology, 29 (1949), 189-200.

Gray, Horace, M.D. and J. B. Wheelwright, M.D. "Jung's Psychological Types, Their Frequency of Occurrence." Journal of General Psychological, 34 (1946), 3-17.

Gray, Horace, M.D. and J. B. Wheelwright, M.D. "Jung's Psychological Types, Including the Four Functions." Journal of General Psychology, 33 (1945), 265-284.

Gray, Horace, M.D. and J. B. Wheelwright, M.D. "Jung's Psychological Types and Marriage." Stanford Medical Bulletin, 2 (1944), 37-39.

Hi11, David 0. Extraversion-Introversion: An Investigation of Typological Theory. Lubbock, Texas: A Doctoral Thesis, Texas Tech University, 1970.

Hollis, Ernest V. and Alice L. Taylor. Social Work Education in the United States. New York: Columbia University Press, 1951.

Jung, Carl G. Psychological Types. Princeton: Princeton University Press, 1971.

Kahn, Alfred J. "The Societal Context of Social Work Practice." Social Work, 10 (October 1965), 145-155. 
Langston, Robert D. "Community Mental Health Centers and Community Mental Health Ideology." Community Mental Health Journal, 6 (October 1970), 387-392.

Lee, Porter R. Social Work ás Cause and Function and Other Papers. New York: Columbia University Press, 1937.

Lubove, Roy. The Professional Altruist. New York: Atheneum Press, 1971.

McNamara, Thomas Charles. A Study of Philosophical Identities in a Counseling Practicum. Urbana, Il7inois: Unpublished Doctoral Dissertation, University of Illinois, 1967.

Mann, Lester. "The Relation of Rorschach Indices of Extratension and Introversion to a Measure of Responsiveness to the Immediate Environment." "Journal of Consulting Psychology, 20 (1956), 114-118.

Meyer, Carol H. Social Work Practice. New York: Free Press, 1976.

Myers, Isabel Briggs. The Myers-Briggs Type Indicator Manual. Princeton: Educational Testing Service, 1962.

Pantleo, Paul Morris. Community Mental Health Ideology: An Analysis of Community Oriented and Traditional Mental Health Facilities. Boulder: A Doctora1 Thesis, University of Colorado, 1971.

Peavy, Richard Vance, Ed.D. A Study of Jung's Concept of Intuitive Type. Eugene, Oregon: A Doctoral Dissertation, University of Oregon, 1963.

Perlman, Helen Harris. "Free Association on Problems of Child Welfare: Putting the Social Back in Social Casework." Child Welfare, 31 (July 1952), 8-9, 14.

Perlman, Helen Harris, ed. Helping: Charlotte Towle on Social Work and Social Casework. Chicago: University of Chicago Press, 1969 .

Richmond, Mary E. The Good Neighbor. Philadelphia: Lippicott, Special Philadelphia Edition, 1908.

Richmond, Mary E. Social Diagnosis. New York: Russell Sage Foundation, 1917.

Richmond, Mary E. What is Social Casework? New York: Russell Foundation, 1922. 
Roberts, Robert and Robert $H$. Nee. Theories of Social Casework. Chicago: University of Chicago Press, 1970.

Rossi, Ascanio M. and Philip Solomon. "Notes on Reactions of Extroverts and Introverts to Sensory Deprivation." Perceptual and Motor Ski11s, 20 (1965), 1183-1184.

Schwartz, Will iam. Private Troubles and Public Issues: One Job or Two? Lecture at the National Conference on Social Welfare, $\overline{\text { May }}$ 28, 1969.

Shapiro, Kenneth and Irving Alexander. "Extraversion-Introversion, Affiliation and Anxiety." Journal of Personality, 37 (1969), $387-406$.

Stephenson, W., Ph.D. "Methodological Consideration of Jung's Typology." Journal of Mental Science, 85 (1939), 185-205.

Stricker, Lawrence J. and John Ross. "Intercorrelations and Reliability of Myers-Briggs Type Indicator Scales." Psychological Reports, 12 (1963), 287-293.

Stricker, Lawrence J. and John Ross. "Some Correlates of a Jungian Personality Inventory." Psychological Reports, 14 (1964), 623-643.

Stroops, Sylvia Lynn. Personality Types and Vocational Interests of Female Students Majoring in Two Different Areas of Teacher Education. Atlanta: A Doctoral Dissertation, University of Alabama, 1971.

Stuckey, F. Robert. Jungian Typblogy and Marital Nonverbal Comat minication. San Diego: A Doctoral Thesis, California School of Professional Psychology, 1975.

Taberi Merlin A. and Anthony J. Vattano. "Clinical and Social Orientations in Social Work: An Empirical Study." Social Service Review (1970) Vol. 44, 34-43.

Terrill, Jerry Lee, Ph.D. Correlates of Counselor Role Perception. Boulder: A Doctoral Thesis, University of Colorado, 1969.

Tranel, N. "Effects of Perceptual Isolation on Introverts and Extraverts." Psychiatric Research, 1 (1962) 185-192.

Veach, T. L. and J. C. Toukey. "Personality Correlates of Accurate Time Perception." Perception and Motor Ski11s, 33 (1971), 765-766.

Weaver, W. Wallace, ed. Frontiers for Social Work. Philadelphia: University of Pennsylvania Press, 1960. 
Webb, Sam C. "An Analysis of the Scoring System of the Myers-Briggs Type Indicator." Educational and Psychological Mea surement, 24 (1964), 765-781.

Woodroofe, Kathleen. From Charity to Social Work in England and the United States. Toronto: University of Toronto Press, 1962.

Yura, Michael Thomas, Ph.D. The Personality Traits and Vocational Interests of Guidance students. Columbus: A Doctoral Dissertation, Ohio State University, 1971. 
APPENDIX 


\section{NUMBER 1}

\section{DEMOGRAPHIC SHEET}
1. Age:
2. Sex

3. Previous experience in social service related fields . . paid or voluntary.

Position

Length of time

4. Please describe the ideal employment position you would desire 5 years from graduation. (Be Specific) 
NUMBER 2

PLEASE CHOOSE YOUR PREFERENCE (ARBITRARILY*) FOR PRACTICE IN A POST GRADUATION EMPLOYMENT POSITION. CHECK ONE (1) OF THE FIVE (5) FOLLOWING PRACTICE AREAS THAT WOULD INVOLVE AT LEAST 80\% OF WORK TIME.

1. A process of therapy and counseling, individual and/or group, emphasizing ego supportive procedures. The therapist considers environmental factors and situational factors, but focuses on helping the client to increase coping abilities and develop insight into inter-and intra personal difficulties. (Examples: traditional psychotherapy, psychoanalys is, private or clinical practice, ego supportive counseling.)

2. Individual and/or group counseling employing specific treatment modalities. The worker believes that the client can learn skills which will enable him to adapt to and better manage his environment. (Examples: Casework with a specific population in need of service, such as geriatrics, public school children, welfare clients, the disabled and others. Private or clinical practice focusing on specific problem areas or treatment modalities, such as sex therapy, marriage and family counseling, gestalt, TA, behavior modification, RET, didactic groups, education and growth awareness seminars, and others.)

3. Activities undertaken in the community with an emphasis on the total community or population and its needs. Emphasis is placed on preventive services and services which attempt to meet needs indirectly through consultation, mental heal th education, outreach efforts and program coordination. (Examples: Work in a community mental health center with a broad community program, community liaison, natural networks specialist, consultation and others.)

4. The practice of creating and planning services to meet present and future social needs. This might focus on a specific program or a broad spectrum of services. Individuals might be involved in directing such planning as well as being responsible for outcome and effectiveness. A planner or administrator is not involved per-

*Note: All practice areas are grossly defined and considered as such. Please choose that which comes the closest to your desires for "idea T" employment. 
sonally in providing direct service to clients. (Examples: Planner, Administrator, or Program Evaluation Specialist.)

5. Any social work practice area which directly and.clearly espouses and involves the worker in radical social work action. This philosophy focuses on social, political and economic reform aimed at the improvement of the quality of life for all citizens of this nation. This extends the definition of social work from treatment and diagnosis to new areas for study and change, such as racial discrimination, violence and poverty. Emphas is is placed on changing the environment rather than treating the individual. (Examples: Such reformers are of ten involved in writing, teaching, public education, and political lobbying, as well as others).

COMMENTS: 
NUMBER 3

February 1, 1978

Dear. Weary Fellow Second Year Students:

We have chosen the second year class as the population for a study of the relationship between the personality of social work students and their philosophy of social work practice. Since you probably join us in the trauma of preparing a research project or thesis, we are sure that you will identify with our need to obtain a high rate of return on our practicum research date.

We have selected 2 tests as our instruments and they take approximately 45 minutes to complete. We are asking for your help in providing data for this study and would appreicate your participation. Please read the instructions and fill them out as indicated, including the short demographic sheet. Please return in this envelope to the box on the table located in the student lounge, as soon as possible.

In our study we will not be treating scores individually, so anonymity and confidentiality are assured. However, if you would like your individual test results, we would be glad to share them with you. If so, sign your name to the bottom of the demographic sheet and we will put them in your box. A copy of the abstract of our study will be posted in the student lounge.

You may make it possible for us to graduate!

Thank you for your cooperation.

Francie E. Buktenica

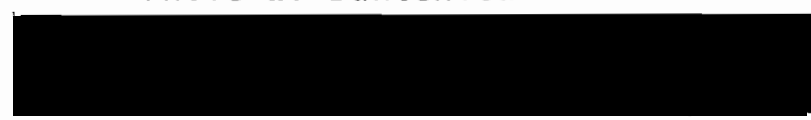

Linda A. Yegge 
NUMBER 4

February 20, 1978

Hi Gang:

Here we are again, to remind you that we're still waiting to hear from those of you who haven't completed your tests.

We realize that you probably want to help us out, but just haven't gotten around to it. Although it does take some time to complete the test, you may find the personality trait profiles that you receive helpful and interesting. Some of our satisfied respondents have commented: "I was simply amazed! Not even my mother knew that!" "Couldn't be more true."

So dig out that envelope from the pile of papers on your desk and become a satisfied customer. (And help us with our project . . please!)

Thanks alot.

Linda Yegge

Francie Buktenica 
NUMBER 5

March 27, 1978

Dear Second Year Students:

We are in a bind! Returns of our study of Social Work Students (their field preference and personality type) has been exceedingly $10 w--40 \%$. We have a great need to receive your response and add it to those already received. Included within are two (2) tests and a data sheet. We would appreciate your cooperation so that our data will be complete.

Scores are treated collectively but should you desire your individual test outcome, please note your name on the bottom of the data sheet and we will deliver the results to your box.

Please return all materials in the envelope provided to the box on the Social Work Student Lounge Table by April 15. A copy of our completed practicum findings will be posted in the Social Work Lounge.

Thank you for your attention in this matter,

Francie E. Buktenica

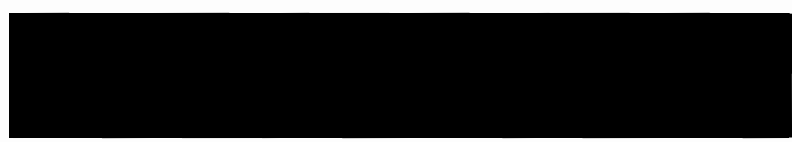

Linda A. Yegge 


\section{NUMBER 6}

Dear Second Year Social Work Student:

Francie and I want to personally thank you for your help in the completion of our practicum. We know the time and effort that went into the project and want you to know you are greatly appreciated. One area of our data brought unexpectedly inconsistant responses and, thus, we have constructed a 5-item question and ask that you bear with us and check off one category and drop it off in our practicum box today. If you area of interest is not listed, please write it in under the category you think is the most similar.

Thanks again and good Tuck in your endeavors!

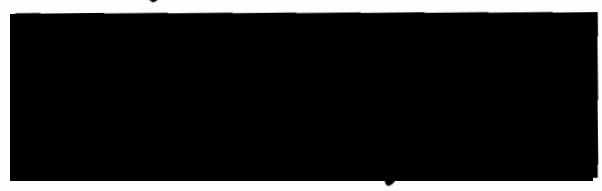

